\title{
Labour parties ideas transfer and ideological positioning: Australia and Britain compared
}

B.M. Edwards \& Matt Beech

School of Humanities and Social Sciences, The University of New South Wales, Canberra

School of Politics, Philosophy and International Studies, University of Hull, UK

As part of this special issue examining policy transfer between the Labour Parties in Australia and Britain, this paper seeks to explore the relationship between the two on ideological positioning. In the 1990s there was substantial ideas transfer from the Australian HawkeKeating government to Blair 'New Labour' in Britain, as both parties made a lunge towards the economic centre. This paper analyses how the inheritors of that shift, the Rudd/Gillard government in Australia and the Milliband and Corbyn leaderships in Britain, are seeking to define the role and purpose of labour parties in its wake. It examines the extent to which they are learning and borrowing from one another, and finds that a combination of divergent economic and political contexts have led to strikingly limited contemporary policy transfer.

Keywords: Australian Labor Party; British Labour Party; Kevin Rudd; Julia Gillard; Ed Miliband; crisis 
In the 1990s there was substantial policy transfer between the Australian Labor Party and the Labour Party in Britain as they confronted the rise of neoliberalism. The ALP was in power from 1983-1996 and introduced far reaching market liberalisation reforms complemented by a strengthened safety net. Due to the economic reforms of Thatcherism, Labour in Britain also remade itself to be more pro-market, drawing considerably on policies of the ALP (Pierson and Castles, 2002). The governments that made the lunge to the economic centre were long-lived, and by that measure successful. However, they bequeathed to their parties the difficulties of re-imagining the modern left. This paper seeks to compare how the ALP and British Labour are undertaking this task, and the extent to which there is borrowing or learning from one another.

Specifically, the research compares how the Rudd/Gillard governments positioned modern Labor in Australia as the first Labor government to take office since Hawke and Keating, and how this compares with how Milliband and then Corbyn have sought to position Labour in Britain in the post New Labour era. The striking finding of this research has been the extent of the divergence between the two parties and how little policy transfer appears to be taking place.

Instead, the parties' attempt to grapple with this challenge has played out through the jostling among competing groupings and traditions. It is possible to plot on an axis the broad economic and social perspectives of the main groupings in each party to illustrate where they stand in relation to each other:

In the Australian Labor party three identifiable ideological worldviews emerged, though they did not necessarily align with the party's formal factions which had become largely institutions of patronage:

1. Old Labor (Interventionist \& social conservative)

2. Inner City Labor (Interventionist \& socially progressive)

3. Keating Labor (Free market \& socially progressive)

Figure 1.

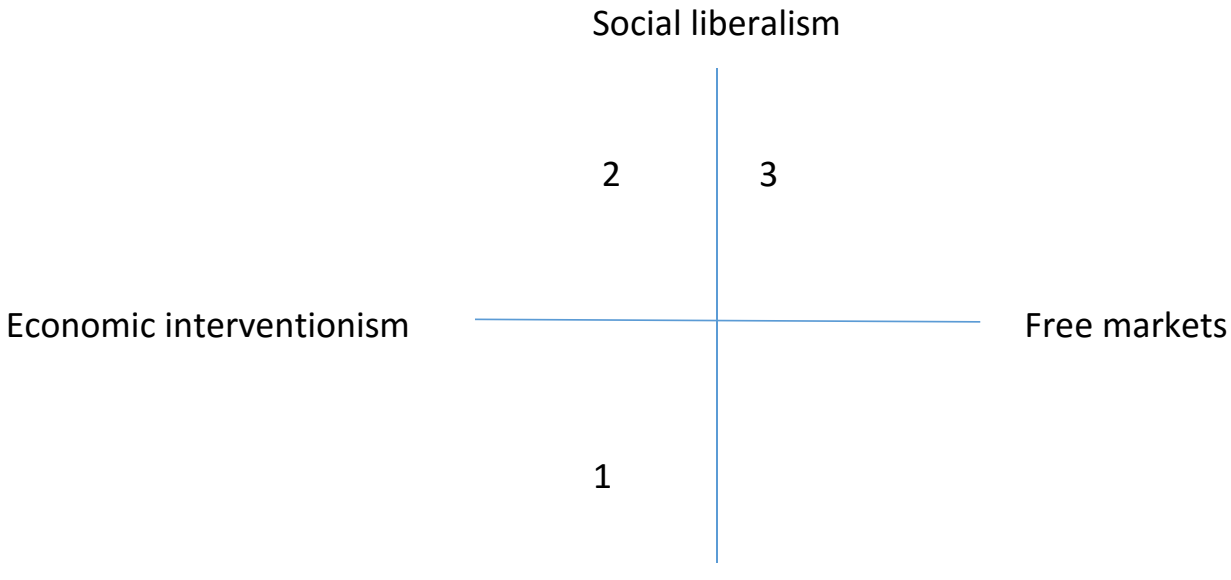

Social conservatism 
At the same time in the British Labour Party it was possible to identify four broad ideological groupings:

1. Blarite progressives (Free market \& socially progressive)

2. Brownite progressives (Pro-market \& socially progressive)

3. Traditional social democrats (Interventionist \& socially progressive)

4. Corbynites/Hard left (Socialist \& socially progressive)

Figure 2.

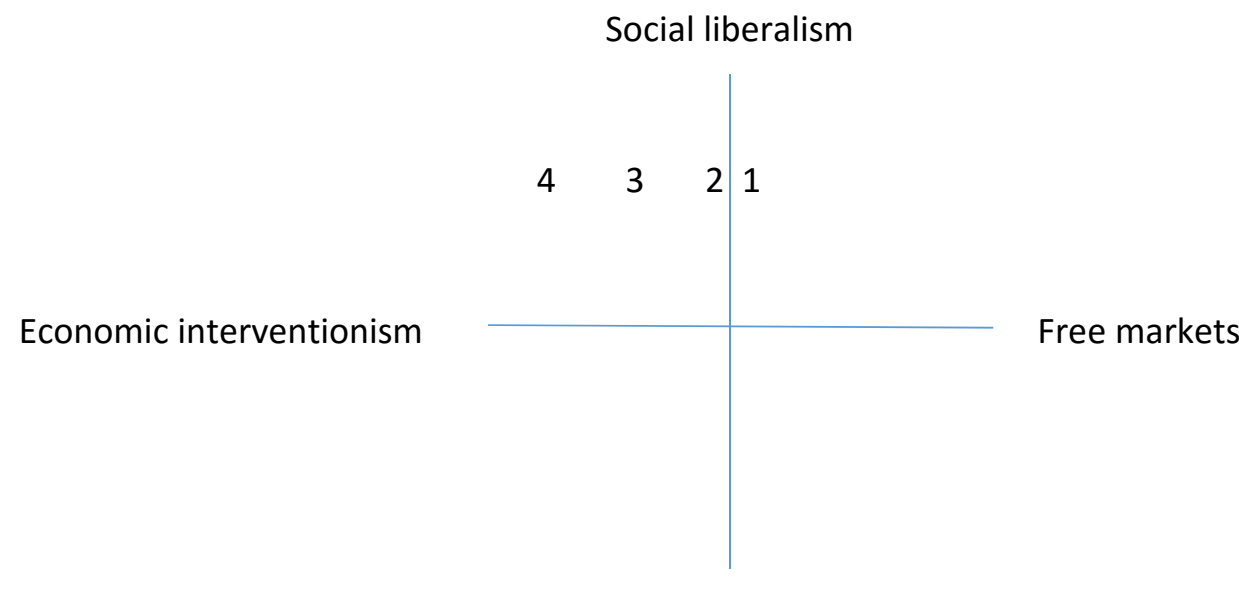

Social conservatism

This research has found that socio-economic and political circumstances have been crucial in dictating which groups have been able to gain traction and influence, and subsequently shape the parties' policy positions in the two countries.

\section{The Australian Labor Party (ALP)}

In order to make sense of the Rudd-Gillard governments' efforts to redefine modern Labor post neoliberalism, it is necessary to outline the challenges they were grappling with. In Australia, the ALP's lunge to the political centre occurred in the 1980s under the leadership of the Hawke-Keating administrations. Those governments oversaw the dismantling of Australia's 'egalitarian settlement' that had been in place since shortly after federation. In response to a perceived economic crisis they tore down Australia's very high tariff barriers, de-regulated the centralized wage fixing system, privatized government services and implemented competition reforms across the economy (Megalogenis 2012; Edwards 2003). Thus the free market agenda that had been implemented by right-wing governments in the United States and Britain were introduced by the ALP. The ALP had argued that the reforms were necessary to underpin ongoing prosperity and growth, and to increase government revenues that were required to provide a strong social safety net. They introduced the social wage that sort to support and compensate the working classes for the loss of security and lifestyle by making major investments in public health, public education and the social welfare system (Battin 1993; Bramble \& Kuhn 2009).

Labor complemented its push to the economic centre with a strong agenda of socially progressive policies (Manning 2007). They argued that Australia needed to move away from its past 
of seeing itself as a 'White Australia' and as part of the British empire, and that instead the nation needed to redefine itself as a multicultural nation in Asia. They were very active in encouraging the role of diverse cultural groups as being central to the life of the nation (Tavan 2012). They were committed to indigenous recognition, land rights and ultimately native title overseeing the most dramatic changes in that policy area in the nation's history. The ALP also supported the advancement of women. The rise of the 'femocrats' under Labor and their championing of female equality saw large strides in public policy towards women in Australia. They were also quite gay friendly, and facilitated Australia's world leading response to the HIV-AIDs threat (Dyrenfurth 2006).

When the Keating government was finally defeated, the election outcome was attributed to a loss of support from Labor's blue collar base. There were extensive debates about whether the party had betrayed its traditions, or whether it had simply undergone a reinvention to continue to pursue its core values in new economic circumstances (Battin 1993, Bramble and Kuhn 2009). There was a period of soul searching about whether their policy direction had been the right one, and what exactly modern Labor should stand for (Bramston 2011). The ALP was awash with differing views about whether it was the economic reforms, the social reforms or both, that had cost the party its heartland. The party can be seen to have splintered into three traditions (Tanner 2010). There were those that supported the 'Old Labor' tradition of being socially conservative and anti-market. This group believed that the Hawke-Keating government had betrayed their traditional base of working class white men on two fronts, undermining both their economic and social standing (Thompson 1999). There was the Labor Left that supported the race and gender equality movements, but believed the party had shifted too far to the right economically and it was the economic reforms that were to blame (Johnson 1989). Then there was a third stream that argued that the Hawke-Keating government had been the most successful Labor government since the Second World War, and that is was longevity and the recession that caused the defeat. They argued that change was painful, but that the basic policy settings were correct and should be celebrated as a great Labor achievement. Importantly, while we can see evidence of these three perspectives in Labor debates, they did not necessarily line up with the party's formal factions that had become primarily institutions of patronage. As a result, the party's traditional mechanisms for dealing with ideological divisions were not functioning effectively. In the years between the fall of the Keating government, and the election of the Rudd-Gillard government, these three traditions tussled in a largely unstructured way over the future direction of the ALP.

\section{Contextual issues}

The way that the three traditions competed was significantly impacted by the practical economic and social circumstances that Australia faced, as well as by the strategic positioning of the opposing Liberal-National Party Coalition. A key consequence of it having been the ALP rather than the Liberals that had initiated the free market reforms was that it served to redefine the central cleavage of Australian politics. Labor's positioning in the economic centre pushed the Liberal Party to redefine how it differentiated itself from Labor. For a decade the Liberals were largely unelectable because they were advocating taking Labor's unpopular free market reforms even further. This was most famously evident in 1993 when Liberal Leader John Hewson lost the 'unloseable election' (Marks and Mitchell 1994). The Liberal Party concluded it was untenable to win power by advocating a further push to the right on economic issues. In 1996 it changed tack, seeking a unity ticket with Labor on economic issues, and instead seeking to distinguish itself as being socially conservative against Labor's progressive positions on race, gender and the environment (Edwards 
2013). John Howard came to power arguing government had been captured by 'minority interests' of the multicultural communities and women's movement and proclaimed that he would stand up for 'mainstream Australians' against their claims. For the next decade 'the culture wars' was deemed the central cleavage of Australian politics (Hindess and Sawer 2004).

Crucially, during the culture wars the political contest became focused on winning over the so called 'Howard Battlers'. In the dominant narrative these were the blue collar voters Howard was believed to have won over with his social conservatism. Howard launched attacks on the latte sipping inner city elites' who advocated progressive values on race, gender and the environment, arguing that he would defend 'ordinary' and 'mainstream' Australians against them (Hindess and Sawer 2004). Labor was unnerved by this discourse that pitted its two key constituencies against one another, and tapped into the powerful sentiment of resentment. Many in the ALP became tentative about the party's ability to win the argument for race and gender equality.

A second feature of the political climate during the Howard years was Australia's experience of a long economic expansion. The upswing that occurred after the early 1990 s recession was carried forward by a mining boom fuelled by the growth of China. While other economies suffered through the Asian Financial Crisis, the bursting of the dot-com bubble, and the Global Financial Crisis, Australia sailed through largely unscathed (Megalogenis 2012). The economy grew strongly, living standards rose, there were labour shortages, and rivers of mining revenue flowed into government coffers. Many issues of economic and political conflict were smoothed over by the ever-expanding national wealth (Megalogenis 2012). There was little imperative to challenge or critique the nation's economic settings. There were modest concerns about growing social inequality, but against a backdrop in which all incomes were rising, albeit at different rates, there was little political momentum to critique the nation's economic policies.

This political context made it difficult for the ALP to define a purpose and vision for the modern left. The practical realities of Australia's economy did not support a traditional critique of corporate power or the excesses and inequalities of capitalism. In the years after Keating they tacked slightly left in in opposing the introduction of the Goods and Services Tax and the sale of Telstra, and the eventually successful campaign against WorkChoices, but for the most part they were unable to offer a coherent alternate approach to the economy. Furthermore, the LiberalNational Coalition's preparedness to fight on issues of race and gender also made establishing the purpose around broader notions of equality politically risky for Labor. This risk was magnified with the 9/11 attacks and the Bali bombings that led to a heightened emphasis on national security. The only real avenue of opportunity that this political context created for the ALP was that when they came to power, the government coffers were full.

\section{Rudd/Gillard/Rudd Labor in office}

The ALP was returned to government in 2007 led by Kevin Rudd and his first ministry governed until 2010. Rudd tendered his resignation in June 2010 after Julia Gillard declared she would challenge him for the party leadership. Gillard led Labor into the 2010 election in which resulted in a hung Parliament with the Liberal-National Coalition winning 73 seats to Labors 72 seats, but after negotiation with several crossbench representatives, Labor was able to govern as a minority administration. In 2013, Gillard was fratricidally deposed by Rudd, in an act of political retaliation. Labor went on to lose the 2013 general election to the Liberal-Nation coalition led by Tony Abbott. 
When Labor, led by Rudd, swept to power in 2007 deposing the Howard administration, they did not articulate a vision that extended far beyond opposing the unpopular industrial relations policy - WorkChoices - and acting upon climate change. The Howard government had presided over an 11 year economic boom and Labor's research picked up that voters were respectful of Howard and his legacy, but believed he had been in office for too long and were open to a safe change (Jackman 2008). Lachlin Harris, Rudd's media adviser, argued that Rudd's key insight was that he needed to position himself as Howard's heir (Killing Season, 2015). Rudd's team set about positioning him as a younger new generation of Howard. The move did not go unnoticed by the electorate with Rudd being variously dubbed 'Howard lite', Junior Johnny, 'mini- John Howard'. The video satirist Hugh Atkin astutely identified that Rudd was operating under 'the clever principle of similar difference'" (Hartcher 2009, p.266). As a result, the party was able to come to power without having articulated a substantial new vision.

The decade before the Rudd victory has been described as Labor's lost decade, "There was no renewal of Labor's values, vision or ideology, let alone any significant enduring policy work done during this period" (Bramston 2011, p.4). The lack of a policy agenda became evident reasonably quickly after taking government. A number of books were published that lamented this lack of vision or policy direction. One argued, "All is not well. Labor suffers from confusion about its progressive mission" (Dyrenfurth 2010, p.209). Another suggests, "Labor's true believers see the party at a defining moment in its history: in government but without an inspiring vision or bold program of reform to animate Labor's values or define its purpose" (Bramston 2011, p.10).

This lack of narrative was feeding into its political effectiveness. The absence of a clear ideological approach led to the Labor government making a string of policy flip-flops that suggested to the electorate that they were lacking moral convictions, and merely making decisions on the basis of strategic political advantage (Sydney Morning Herald Editorial, 2013). However, these flip-flops can be understood as evidence of an unsettled ideological debate. Such policy shifts can be seen to have run along the fissures between the competing ideological traditions within the party. The leadership group of Rudd, Gillard, Swan and Tanner included representatives of each of the traditions. Rudd was stronger on socially progressive issues about the environment and race (Jackman 2008), while Gillard positioned herself as the champion of Labor's socially conservative blue collar base (Johnson 2011). Tanner was a champion of free markets that described big business as the engine of growth (Tanner 2012) while Swan described them as an exploitative elite of oligarchs that were hell bent on redistributing the nation's wealth to themselves (Swan 2012). As the government flitted between these competing positions they gave the impression of an administration with no clear guiding values, and instead, a media driven sound-bite machine that made decisions on the basis of political expediency. The result was politically devastating, "The paradox is extraordinary, many of Labor's senior politicians are some of the most talented ever produced; but, collectively, they are a disaster - as the standing of the government attests" (Bramston 2011, p.17).

Despite the ideological fog, a careful examination of the Rudd/Gillard/Rudd governments' policy track record indicates that a coherent ideological position did emerge, if by default. These issues can be seen as consensus issues between the ALP's competing traditions. They all agreed on economic redistribution, so Labor repeatedly cut entitlements and tighten benefits for high income earners while expanding benefits and support for the less well off (Budget Review 2008-09; Dusevic 2011). There was also consensus on the importance of public health and Labor sort to reinvigorate public health as the primary universal health system. They removed the carrots for the rich and the 
sticks for the poor that the Howard government had put in place to encourage people into private health insurance. They made major investments in the public health system to reinvigorate it and introduced the National Disability Insurance Scheme (Budget Review 2010-11). Finally, they began a reform process of Australian school funding called the Gonski reforms that if it had been fully implemented would have seen a major shift in resources and students from the private education system to the public education system (Parliamentary Library 2013). As a result, despite the ALP's struggles to articulate its identity and purpose, it can be seen to have nonetheless adhered to a distinctly modern left agenda that distinguishes it from the right of Australian politics. The lived values of the ALP are that it supports a more equal income distribution and universal access to public health and public education. The ALP also holds notionally progressive positions on the environment, race and gender, though it has proven itself to be tentative on these issue when under pressure. The party is still significantly divided over how socially progressive it should be, and unsure of how to position itself regarding economic elites and the dynamics of the free market.

\section{The context to the crisis of the British Left: From the GFC to Jeremy Corbyn}

The UK's experiment with New Labour began more than a decade after the ALP's reforms. There are parallels as well as differences in their respective stories. Both parties governed continuously for 13 years and in that time their leaderships adopted a form of neo-liberal political economy: Hawke-Keating 1983-1996 and Blair-Brown 1997-2010. It is has been suggested that the Blair governments followed their sister party, the ALP, in this strategic change of political economy (Pierson and Castles 2002). Evidence for such a claim can be found in New Labour policies for the independence of the Bank of England, keeping the top rate of income tax at $40 \%$, the use of Private Finance Initiatives to fund public sector projects, 'contracting out' public service jobs to the private sector, and permitting the City of London to trade without robust state regulation.

However, while the ALP's embrace of 'new' Labor free market policies was at least in part a response to a perceived economic crisis, the UK's embrace was more narrowly in response to the political crisis facing the left. Both nation's economies are largely post-industrial. The UK is dominated by its financial services sector with manufacturing merely accounting for approximately $10 \%$ of Britain's Gross Value Added (GVA) (Rhodes 2015). A significant externality of British deindustrialization, similar to Australia, has been the diminution of its industrial working class. Unlike Australia, however, the UK does not have compulsory voting. Therefore, many British citizens who choose not to vote are those in poverty - either the working poor, the sick or those who choose not to work - and they live at the margins of society. This sociological change impacted Labour significantly and compelled the Labour Party to modernise initially under Neil Kinnock, then John Smith and most fully in the mid-1990s under Tony Blair. 'New Labour', as Labour was rebranded, occupied a centrist position and sought to appeal to the new, upwardly mobile, middle classes. It targeted those citizens who abandoned Labour during the 1980s to vote for Margaret Thatcher, and saw in her populist Conservatism an aspirational narrative of 'getting on', owning a home and enjoying the fruits of an expanding market economy. Without a large industrial working class base, Labour's evolution was not only inevitable, but also necessary for the party to meaningfully contest elections in a changed economic and social context.

Furthermore, the legacy of New Labour in the UK is perceived quite differently to that of Hawke and Keating in Australia. The Blair-Brown government's long period in office culminated in the worst recession in modern memory. Because of its large financial services sector, the UK was badly exposed to the Global Financial Crash (GFC) of 2008, and suffered a very deep recession. The 
Brown Labour Government responded by putting in place a string of emergency measures including the nationalisation and part-nationalisation of the mainstay of the banking industry; quantitative easing; job creation; and maintaining welfare programmes (Beech 2011). These measures though vastly expensive were designed to prevent a deep recession evolving into depression. In quarter four of 2009 the British economy exited the deepest recession in modern memory (Allen 2010). The Keynesian hand of government, staved off economic meltdown. Nonetheless the ConservativeLiberal Coalition did not assign the UK's large deficit solely to the emergency measures and attributed it in significant measure, to the tax and spend policies of the New Labour years. During the course of the 2010 general election both Labour and the Conservatives pledged to reduce the deficit by cutting public expenditure significantly and the outcome - a hung parliament - was historic in British politics in the post-war era. After 13 years the nation clearly wanted a change from the Labour Party but had reservations about the Conservative Party.

The Labour Party lost office at the general election of 2010 and, after five days of intense negotiation, a coalition government; the first in the post-war era, was formed. The Coalition comprised the Conservative Party under David Cameron and the Liberal Democrats led by Nick Clegg. At first glance such a partnership seemed extraordinary but there existed an overlapping ideology between the elites of both parties predicated on liberalism (Beech 2015), especially between Cameron and Clegg, which facilitated a political agreement that lasted the full five year parliamentary term (HM Government 2010).

The leadership of Ed Miliband attempted to move on from New Labour not only in terms of economic policy and attitudes to the Iraq War, but also in terms of tone and rhetoric. The leitmotif of his tenure was that in an era of austerity it was not merely the poor who were struggling under the Conservative-Liberal Coalition but average workers and members of the middle classes also. For Miliband, the majority of citizens were part of the 'squeezed middle' (BBC News 2010b). They were those outside of the wealthy classes who were anxious about paying their mortgages or failing to get on the housing ladder; citizens seeking better paid work or needing to reskill in the aftermath of the GFC and widespread redundancies from the public sector. Under Miliband Labour had periods of robustly opposing the Conservative-Liberal Coalition and influencing political debate such as his call for a 'responsible capitalism' (Miliband 2011) and challenging the 'big six' energy companies over the need for a price freeze (Miliband 2013). Nonetheless, Labour failed to gain sufficient public traction on their agenda and their task was necessarily difficult because in the Conservative-Liberal Coalition they faced two political opponents united in their contention that Labour could not be trusted to effectively manage the economy. Furthermore, Miliband's personal history as a Brownite advisor and then a loyal cabinet minister demonstrated he was too embedded in the politics - both good and bad - of the New Labour years. An emergent problem was the growing perception that Miliband lacked the natural ease of Cameron or Clegg and was prone to gaffes. In fact, Labour's perceived policy weakness primarily on the issue of deficit reduction, ability to run a successful economy and, crucially, on immigration proved to be much more decisive at the general election than whether their leader was too much of a 'geek' or a 'North London socialist'. For many voters, Milband's Labour were too liberal on immigration - especially from within the EU - though not even HM Government could prevent mass migration due to the principle of free movement of EU citizens; and voters largely agreed that Labour was wedded to public expenditure when budgetary restraint was the order of the day.

In 2010 Labour won 258 seats; received 8.6 million votes; and gained $29 \%$ of the total vote (BBC 2010a) compared to 2015 when it won 232 seats; received over 9.3 million votes; gaining 
$30.4 \%$ of the total vote (BBC 2015b). Despite 700,000 more votes in 2015 , Labour's share of the vote only increased by $1.4 \%$ and they gained 26 fewer seats in parliament. This was surprising given the controversial nature of the Coalition's policy of austerity and its popularity level over the course of the Parliament (NatCen 2015). The result was further complicated by the rise of UKIP and the SNP in frontline British politics. As well as its customary eurosceptic right-wing base, UKIP support is drawn from more conservatively inclined Labour supporters within the white working class (NatCen 2015); in total UKIP received 3.88 million votes across the UK making it the third party in British politics in terms of popular support with $12.6 \%$ of the share of the vote (BBC News 2015a). In Scotland, a traditional Labour heartland, the SNP standing on a centre-left manifesto replaced Labour as the party of choice winning 53 of the 56 seats and securing $50 \%$ of vote share (BBC News 2015a).

In the wake of the loss, Labour like their Australian cousins, are divided over ideas and policy. Interestingly, where the ALP has had a discernible divide between social conservatives and progressives, in the UK the Labour Party's world view (that of the majority of the Parliamentary Party and party activists) is firmly secular progressive. Its default position has been to support the advancement of the liberation movements. Evidence to substantiate this claim is to be found in the Adoption and Children Act (2002), Civil Partnership Act (2004), the Equality Act $(2006 ; 2010)$ and, the Marriage (Same-Sex Couples) Act (2013) drafted by the Conservative-Liberal Coalition, but passed due to the overwhelming support of Miliband's Labour. The Labour Party is noted as the mainstream party most committed to gay rights, abortion, feminism and the Human Rights Act (1998). The policy area which saw the sharpest division between the left and right was the decision to go to war in Iraq in 2003. Whether one classifies it as neo-conservative statecraft, liberal interventionism or neither, the controversy was such that Labour became riven over security, defence and foreign policy which irrevocably damaged Blair and sullied New Labour's reputation and legacy.

However, the Labour Party is much more divided over political economy. The groupings plotted on figure 2 include: 1 . the Blairite progressives who endorse market liberalism (Philpot 2011); 2. the Brownite progressives who are pro-market but more willing to use the state (Brown 2003); 3. the traditional social democrats who are advocates of Keynesian big government (Hattersley and Hickson 2013); and 4. the Corbynite/Hard left who advocate widespread public ownership (Clarke and Gardner 2011). Added to this are those Members of Parliament best understood as Labour centrists/party loyalists who do not identify with a particular ideological grouping, but rather seek to hold Labour's broad church together to best defeat the Conservative Party at elections.

The crisis in Labour is most evident in the 2015 Labour Leadership contest when hard left socialist - Jeremy Corbyn - triumphed over the more centrist Andy Burnham, the Brownite Yvette Cooper and Liz Kendall from the Blairite right wing. Of the 422,871 votes cast, Corbyn gained 251,417 or $59.5 \%$ with Burnham a distant second on $19 \%$, and this was all the more decisive as Corbyn secured $50 \%$ or above across the three sections of the electorate: members, registered supporters and affiliated supporters (BBC News 2015c). Corbyn gained 36 nominations ( 35 being the requisite number to enter the contest), Burnham received 68 nominations, Cooper 59 and Kendall 41 (The Staggers 2015). Corbyn garnered the necessary number of nominations due to the support of a small band of non-Labour left MPs who decided to nominate him for the benefit of broadening the policy debate, during a long campaign, in the confidence he had no chance of winning. The result is that Labour elected its most left-wing Leader in the post-war era, overwhelming chosen by the majority of card-carrying activists, newly registered supporters and affiliated members from the 
trade unions and allied socialist organisations. There exists here a disjuncture of values between Labour activists, Labour voters and those the party wants to capture at the 2020 general election (Kellner 2015).

\section{Conclusion: Labour and the ALP - similarities and differences}

The comparison of Australian and British Labour highlights that both parties are struggling with the process of reinvention and re-definition. In their initial adaptation to neoliberalism both parties made a lunge to the economic centre, and coupled that with embracing progressive positions on race and gender. However the differing timing and context of those moves have created different legacies that the two parties are now trying to grapple with.

The difference in the timing and the economic legacies of the adaption to neoliberalism is perhaps the most pronounced difference. The Hawke-Keating government was the initiator and architect of Australia's free market reforms. Among policy elites it is widely credited with having brought much needed reform to the Australian economy by both sides of politics, and is often credited with having laid the foundations of the long boom that followed. Arguably, much of Australia's economic good fortune comes down to the impact of the mining boom. Nonetheless, the apparent success of economic policies in delivering a sustained period of rising living standards meant there was little impetus to repudiate the economically centrist position. Furthermore, as the public had a sanguine attitude to the Howard government and there had been little in the way of gross economic failures, it made it difficult for Rudd/Gillard to do anything other than continue with an economically centrist position.

In contrast, the British Labour Party ended up carrying the burden of economic circumstances which were, arguably, equally outside government control but in that instance tarred the Party with notions of economic mismanagement. The economic hardship in Britain, combined with a public that became highly critical of the New Labour administrations has spurred the party to go through a dramatic transformation. Voter disillusionment with centrist politics has driven the electorate to split right and left. Those splitting to the right shifted their vote to the Conservatives and UKIP and those who tilted left argue seem to view Miliband's Labour as firmly pro-market and too similar to Blair and Brown's offerings, and so, voted Green or SNP in Scotland. Under fresh rules for electing its leader - designed by Miliband's team - Labour members and many new, young, 'supporters' agreed with this leftist analysis and believing that Labour under Corbyn could effectively build for Britain a 'new Jerusalem' they unanimously elected a member of the Socialist Campaign Group and, by so doing, pushed Labour back to a much more left-wing position on the economy, foreign policy and defence.

Context has played a similarly important role in how both parties are positioning themselves on liberation movement issues of race, and to a lesser degree gender. Both parties have faced a loss of blue collar voters who are socially conservative and energized around issues of race and immigration. However the challenge has played out very differently in the two countries. In Australia the Coalition parties moved into that space, and made the question of the 'culture wars' a central political cleavage between the major parties. The manoeuvre split the ALP's key constituencies and Labor have responded by adopting a relatively socially conservative line to hold onto their blue collar base. In contrast, in Britain both of the major parties have held the line on socially progressive policies, leaving that section of the electorate to be wooed away by UKIP and SNP. Those that are mobilized by those issues have become a new third force in British politics.

These differing circumstances have left the two parties adopting remarkably different political positions at the time of writing. The ALP has been pushed towards a status quo centre from which it is arguably more flexible and more able to get elected, but it is much more difficult to make 
arguments for genuinely egalitarian reforms. In contrast events have boxed the UK Labour Party into a more left wing position from which is looks like it will be more difficult to win widespread support, but it has also given it the armoury to make arguments for more reformist changes and arguments for greater equality. The comparison of the two parties highlights how important context is in shaping policy transfer. In the 1980s and 1990s there were sufficient parallels in the challenges that the two parties faced, that they were able to share solutions. However, as their circumstances have diverged, policy transfer has dried up, and the parties have taken very divergent paths. 


\section{References}

Australian Government Funding for Schools Explained : 2013 Update. 2013. Parliamentary Library, Parliament of Australia.

Budget Review 2008 - 09. 2008. Parliamentary Library, Parliament of Australia.

Budget Review 2010 - 11. 2010. Parliamentary Library, Parliament of Australia.

Allen, G., 2010. Key issues for the new parliament 2010: recession and recovery. London: House of Commons Library, http://www.parliament.uk/documents/commons/lib/research/key issues/KeyIssues-Recession-and-recovery.pdf accessed 20 September 2015.

Battin, T., 1993. A break from the past: The Labor Party and the political economy of Keynesian social democracy. Australian journal of political science 28 (2) July, 221-241.

BBC News, 2010a. Election 2010: results. http://news.bbc.co.uk/1/shared/election2010/results/ accessed 21 August 2015.

BBC News, 2010b. Miliband comes to defence of 'squeezed middle' http://www.bbc.co.uk/news/ukpolitics-11848303 accessed 23 November 2015.

BBC News, 2015a. Election 2015: SNP wins 56 out of 59 seats in scots landslide.

http://www.bbc.co.uk/news/election-2015-scotland-32635871 8 May, accessed 3 September 2015.

BBC News, 2015b. Election 2015: results. http://www.bbc.co.uk/news/election/2015/results accessed 21 August 2015.

BBC News, 2015c. Labour leadership results in full. http://www.bbc.co.uk/news/uk-politics$\underline{34221155} 12$ September, accessed 20 September.

Beech, M., 2011. A tale of two liberalisms. In S. Lee and M. Beech, eds. The Cameron-Clegg government: politics in an age of austerity. Basingstoke, UK: Palgrave Macmillan, 267-279.

Beech, M., 2015. The ideology of the coalition: more liberal than conservative. In: M. Beech and S. Lee, eds. The conservative-liberal coalition: examining the Cameron-Clegg government. Basingstoke, UK: Palgrave Macmillan, 1-15.

Bramble, T., and Kuhn, R., 2009. Continuity or discontinuity in the recent history of the Australian Labor Party? Australian journal of political science, 44 (2) June, 281-294.

Bramston, T., 2011. Looking for the light on the hill: modern Labor's challenges. Melbourne: Scribe.

Brown, G., 2003. State and market: towards a public interest test. The political quarterly, 74 (3) JulySeptember, 266-284.

Clarke, E., and Gardner, O., eds. 2011. The red book: Labour left. London: Labour Left, http://www.labourleft.co.uk/wp-content/uploads/2012/03/74185392-The-Red-Book.pdf accessed 29 August 2015. 
Dusevic, T., 2011. Milking the rich - the great redistribution. The Australian, May 11.

Dyrenfurth, N., 2006. Rethinking Labor tradition: synthesising discourse and experience. Labour history (90) May 177-199.

Editorial. 2013. Australians deserve a government they can trust. The Sydney morning herald, September 6.

Edwards, L., 2003. How to argue with an economist: re-opening political debate in Australia. Melbourne: Cambridge University Press.

Edwards, L. 2013. The passion of politics: the role of ideology and political theory in Australia. Sydney: Allen \& Unwin.

Hartcher, P., 2009. To the bitter end: the dramatic story behind the fall of John Howard and the rise of Kevin Rudd. Crows Nest: Allen \& Unwin.

Hattersley, R., and Hickson, K., eds. 2013. The socialist way. London: I.B. Tauris.

HM Government, 2010. The coalition: our programme for government. London: The Cabinet Office.

Jackman, C., 2008. Inside Kevin07: the people. the plan. the prize. Carlton: Melbourne University Press.

Johnson, C., 1989. The Labor legacy: Curtin, Chifley, Whitlam, Hawke. Sydney: Allen \& Unwin.

Johnson, C., 2011. Gillard, Rudd and Labor Tradition. Australian journal of politics and history, 57 (4), 562-579.

Kellner, P., 2015. New polling data shows the challenge facing Jeremy Corbyn. New Statesman, 23 September http://www.newstatesman.com/politics/uk/2015/09/new-polling-data-shows-challengefacing-jeremy-corbyn accessed 24 November 2015.

Kelly, P., 1992. The end of certainty: the story of the 1980s. Crows Nest: Allen \& Unwin.

Manning, H., 2007. The ALP and the union movement: 'catch-all' party or maintaining tradition? Australian Journal of Political Science, 27 (1) September, 12-30.

Marks, G.N. and Mitchell, J., (1994) Explaining Labor's win at the 1993 federal election. International Journal of Public Opinion Research, 6 (3) 241-263.

Megalogenis, G., 2012. The Australian moment: how we were made for these times. Melbourne: Penguin Australia.

Miliband, E., 2011. A new economy. Speech to the Social Market Foundation. London: Labour Party, 17 November http://www.newstatesman.com/economy/2011/11/term-business-government accessed 20 September.

Miliband, E., 2013. Speech to the Labour party conference. London: Labour Party, 24 September http://labourlist.org/2013/09/transcript-ed-milibands-2013-conference-speech/ accessed 20 September. 
NatCen. 2015. British social attitudes: the verdict on five years of coalition government. Press release 26 March, https://www.natcen.ac.uk/news-media/press-releases/2015/march/british-socialattitudes-the-verdict-on-five-years-of-coalition-government/ accessed 3 September 2015.

Philpot, R., ed. 2011. The purple book: a progressive future for labour. London: Biteback Publishing.

Pierson, C., and Castles, F.G., 2002. Australian antecedents of the third way. Political Studies, 50 (4), 683-702.

Rhodes, C., 2015. Manufacturing: statistics and policy. Briefing paper no 01942. London: House of Commons Library file:///C:/Users/Matt/Downloads/SN01942.pdf accessed 21 August 2015.

Sawer, M. and Hindess, B., 2004. Us and them: Anti-elitism in Australia. Perth: API Network.

Swan, W. 2012. The 0.01\%: the rising interest of vested interests is threatening Australia's egalitarian social contract. The Monthly (March), 20-24.

Tanner, L., 2012. Politics with purpose: occassional observations on public and private life. Melbourne: Scribe.

Tavan, G., 2012. No going back? Australian multiculturalism as a path-dependent process. Australian journal of political science, 47 (4) December, 547-561.

The Staggers, 2015. Who nominated who for the 2015 Labour leadership contest? London: New Statesman http://www.newstatesman.com/politics/2015/06/who-nominated-who-2015-labourleadership-election 15 June, accessed 20 September.

Thompson, M., 1999. Labor without class: the gentrification of the ALP. Melbourne: Pluto Press. 